\title{
Groundwater Exploration in the Basement Complex Around Chibok Area in North- Eastern Nigeria Using Vertical Electrical Sounding Method
}

\author{
1I. M. Abdullahi, ${ }^{1}$ N. A. Yelwa, ${ }^{2}$ A. Abdulmumin and ${ }^{3}$ N. A. Nabage \\ ${ }^{1}$ Department of Geology, Usmanu Danfodiyo University, Sokoto-Nigeria \\ ${ }^{2}$ Adamawa State Water Board, Yola-Nigeria \\ ${ }^{3}$ Department of Applied Geology, Abubakar Tafawa Balewa University, Bauchi-Nigeria \\ [Corresponding author: Email: ibrahimohab@gmail.com]
}

\begin{abstract}
A geophysical survey employing Schlumberger electrode configuration using vertical electrical sounding (VES) method was carried out around Chibok area within the Basement Complex of north-eastern Nigeria using an ABEM SAS $300 \mathrm{C}$ Terrameter with a view to exploring groundwater within the study area. The overburden in the area ranges from about $15 \mathrm{~m}$ to $58.5 \mathrm{~m}$ thick. This overburden, based on geoelectrical interpretations, consists essentially of top soil, decomposed crystalline rock, highly weathered crystalline rock, weathered or fractured crystalline rock and weathered to fresh crystalline rock. The study suggest that the vicinities of all the VESs are best suited for the siting of boreholes apart from VES 1 and 5 due to the presence of fresh crystalline rock at shallow depth.
\end{abstract}

Keywords: Hydrogeology, Basement Complex, Alluvium, Colluviums, Electric resistivity, Chibok

\section{INTRODUCTION}

Groundwater exploration within the basement complex rocks of Nigeria is usually carried out with the use of Vertical Electrical sounding (VES). Chibok town is located on the Basement Complex of Northeastern part of Nigeria on the Mandara Hills Borno State within latitude $10^{\circ} 50^{\prime} 00^{\prime \prime}$ to $10^{\circ} 50^{\prime} 40^{\prime \prime} \mathrm{N}$ and longitude $12^{\circ} 15^{\prime} 15^{\prime \prime}$ to $12^{\circ} 52^{\prime} 00^{\prime \prime} \mathrm{E}$ (Figure 1). The study area is underlain by the undifferentiated rocks of the Basement complex which have been subjected to weathering that produced a fairly deep regolith (Kogbe, 1989). The Basement Complex rocks are mainly granite in composition, on different stages of metamorphism, forming gneisses, migmatites rocks with low permeability and generally not water bearing. In most areas underlain by the Basement complex is a thin, discontinuous mantle of weathered rocks. The average thickness of the mantle is $15 \mathrm{~m}$, but in some areas may extent to depths of up to $60 \mathrm{~m}$ (Arabi et.al. 2010). However, where the Basement Complex rocks are fractured and/or weathered it is possible for the rocks to be porous and permeable, and thus able to store and transmit water. Unlike in sedimentary basins, where an aquifer may extend to a considerable distance, occurrences of water in Basement Complex rocks are in pockets restricted to fractured and weathered zones.
Any elaborate groundwater development scheme in the basement region requires a quantitative knowledge of hydro-geophysical parameters of the hydro-geologic units, that is, the superficial materials overlying the crystalline bedrock and the structures/relief.

In this research, a detailed hydro-geophysical exploration of the area around Chibok has been carried out with the intention of determining the geoelectric parameters, (layer, resistivity and thickness) of the superficial/overburden materials overlying the bedrock, the subsurface structural disposition of the bedrock and their hydrogeologic characteristics. The exploration utilized geoelectrical and hydrogeologic parameters of the Basement Complex setting.

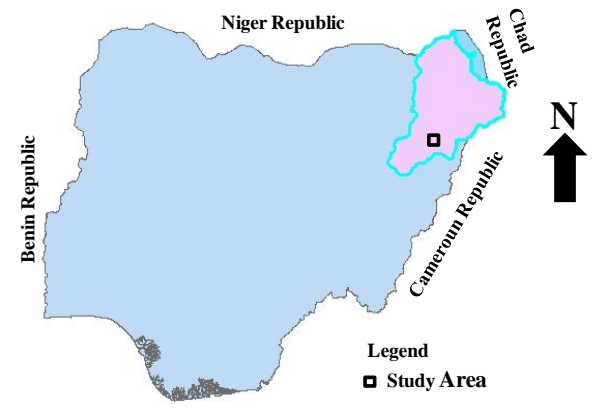

Figure 1: Location map of the study area (Drawn not to scale)

According to Nur and Kujir, 2006, groundwater is normally found if the original state of the rock has been deformed either by deep fracturing, 
weathering, faulting among others. The presence of groundwater in any given area depends on the thickness and lateral extent of decomposition and where both occur, the groundwater condition is usually very good (Arabi et al., 2010).

A number of geophysical survey investigations has been carried out adjacent to the study area, Damboa $30 \mathrm{~km}$ from the north and Askira $27 \mathrm{~km}$ from the west, south-east of the study area by Conred (1978) with a view to delineating groundwater bearing formations. Similarly, Federal Government of Nigeria through the Federal Ministry of Water Resources (FMWR) under the Chad Basin Development Authority's Water Supply Intervention Scheme in 2001, carried out survey in six local government in Borno south senatorial districts (including Gwoza local government) but most of the boreholes drilled were either of low yield or abortive (Arabi et.al. 2010).Three water bearing zones were delineated, these are: the weathered and the fractured part of the basement rock and the thick alluvial deposit that overlies it in the case of Askira (basement area). At Damboa, a coarse sandy zone which is considered as part of the Kerri-Kerri Formation of the Chad Basin.

\section{Regional Geologic Setting}

The geology of Chibok is made up of two main units, namely, the crystalline rocks of the Basement Complex and the superficial alluvial deposits mainly within the intermontane valleys and plains. The Basement Complex is exposed mainly in the central part of the Chibok and is made up of granites and undifferentiated metamorphic rocks. These rocks constitute the principal and oldest stratigraphic unit in Nigeria and consist mainly of granites schistose rocks (Conred 1978; Mutah 2002). The Basement region, in which the study area lies, is exposed over much of the southern part of Borno State, and is defined tectonically by fault bounded basins containing sediment which vary in age from Cretaceous to Quaternary (Figure 2a).

The Basement Complex region of Borno is affected by a dense pattern of fault and fractures which is either intensified in the proximity of the two Upper Cretaceous graben structure, and the dense network trend dominantly South-East towards the Benue Basin Conred (1978).

The geology of the study area shows Basement Complex gneissic granites overlain by extensive alluvium and young alluvium with more restricted deposits of colluvium.

Basement Complex includes all the Premesozoic rocks in Nigeria. It consists mainly of granites, gneisses, migmatites, with subordinate base rocks.

In order of age, from oldest to the most recent, it is possible to distinguish the following litho types:-

- Gabbro and diorite

- Undifferentiated migmatite rocks.

- Granite-gneisses.

- Granites.

- Dykes

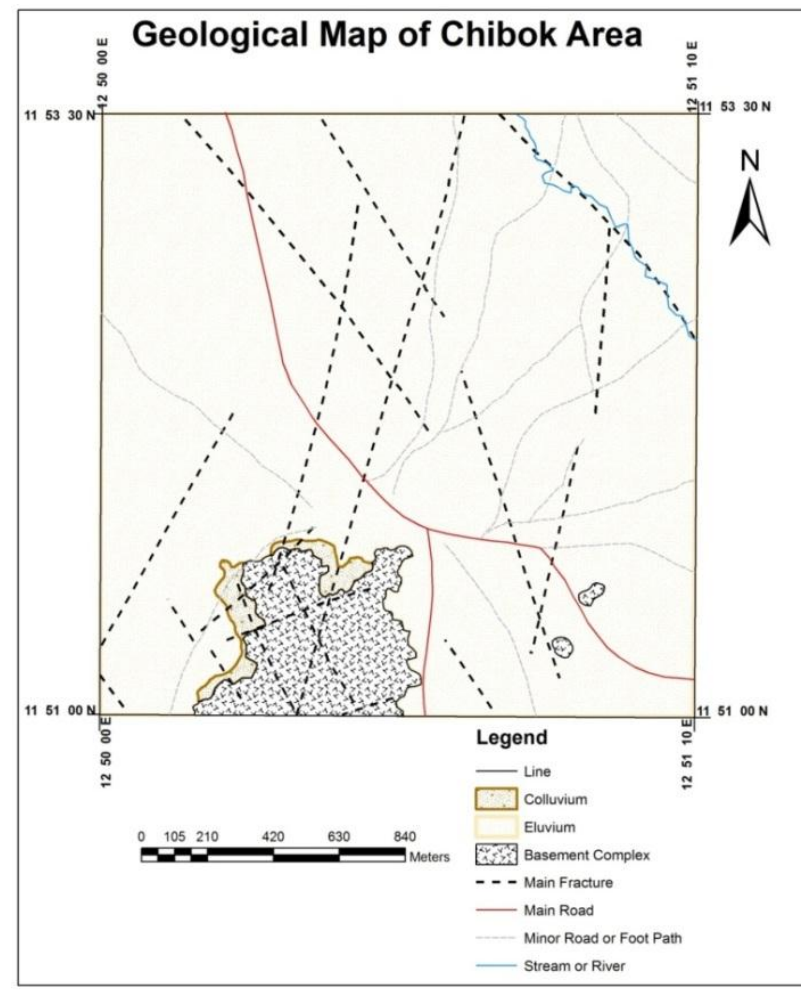

Figure 2a: Geologic Map of Chibok Area

Alluvial Deposits:This geologic unit includes most soils and comprises those deposits formed insitu by the chemical and physical decomposition of bedrock. It occurs wherever weathering exceeds the rate of the erosion and 
is therefore best developed in topographically subdued area.

Alluvium covers about $60 \%$ of the study area and occupies the slightly elevated ground between the two main drainage systems on which study area as situated. This alluvial deposits which is mostly due to seasonal flooding in the study area, is mostly of fine to silty sand has been deposited over a wide area. It also found along the narrow river channels, in few meters deposits of medium sand.

In the study area, it found a few principal river channels which are broader and gently meandering with clean, coarse sandy bottoms.

Colluvium: - This unit is not widespread in the study area. The term colluvium is intended here as colluvial deposits i.e. composed of debris accumulated by gravity and/or deposited by unconcentrated surface runoff or sheet erosion. It is not concentrated along the water coarse and generally has much coarse grain with little or no classifications (Figure 2a).

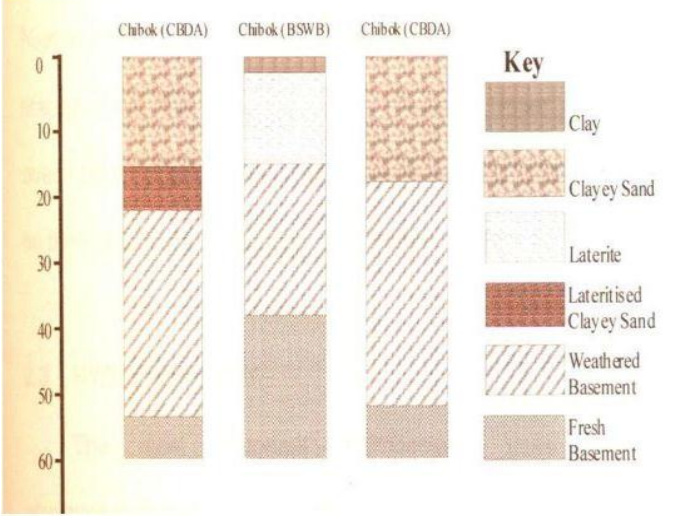

Figure 2b: Lithologic Logs of some boreholes drilled in the study area. (Chad Basin Development Authority \& Borno State Water Board, 1989).

\section{Hydrogeology}

The most important hydrogeologic units are the alluvium/weathered zone of the Basement Complex area, the fracture zone of the Basement rocks and the sediments of the Chad Basin (Figure 2b). Evidence from the depth of hand-dug wells suggest that thickness of the alluvium/weathered zone may be up to $5 \mathrm{~m}-7 \mathrm{~m}$ in places within the intermontane areas and western part of the Local Government Area. Groundwater levels vary within the Local Government Area from $2 \mathrm{~m}-8 \mathrm{~m}$ below ground level in the entire area (Conred, 1978).

\section{METHODOLOGY}

Electric resistivity method using Schlumberger array configuration was employed in this study. This involved the use of ABEM Terrameter SAS 300 and its accessories. Distance of $100 \mathrm{~m}$ each of electrodes is placed in straight line on the surface of the earth at each VES point.

\section{Field procedure}

The current electrodes $A$ and $B$ were connected to terminals $\mathrm{C}_{1}$ and $\mathrm{C}_{2}$ and the potential electrodes $\mathrm{M}$ and $\mathrm{N}$ were connected to terminals $P_{1}$ and $P_{2}$. Schlumberger array were adopted throughout the survey (Figure $3 a$ and 3b).

Electrical sounding were carried out by extending electrode system on a straight line to produce vertical changes to the various strata layers encountered with a condition that $A B / 2>$ $5 \mathrm{MN}$. This condition has to be fulfilled at all times for the array to be valid. The survey started at a short distance of $A B / 2$ which was then increased progressively as the survey continued. At a certain period, the potential distance (MN) has to be increased. The resistivity values were obtained directly from the terrameter at each measurement is multiplied by the geometrical factor $(\mathrm{K})$ approximate to the electrodes spacing to obtain a series of apparent resistivity values.

The depth of penetration increases with increasing electrodes spacing. A graph is obtained by plotting the apparent resistivity values against electrode spacing $A B / 2$ on a bilogarithmic paper for further processing.

Eight VES points with $A B$ separation of 200 meters were sounded. $A B / 2$ varied from 1 meter to 100 meters. Twenty five measurements of $A \Delta / I$ were made. The potential electrode separation $P_{1} P_{2} / 2$ varied from 0.2 volts to 8 volts. 
A straight traverse with 200 meters separation between successive VES points was made in NE-SW directions.

Typical data acquisition procedures for the present work involved the following discrete stages:

a. Reconnaissance survey.

b. Mobilization of equipment and personnel to site

c. Layout

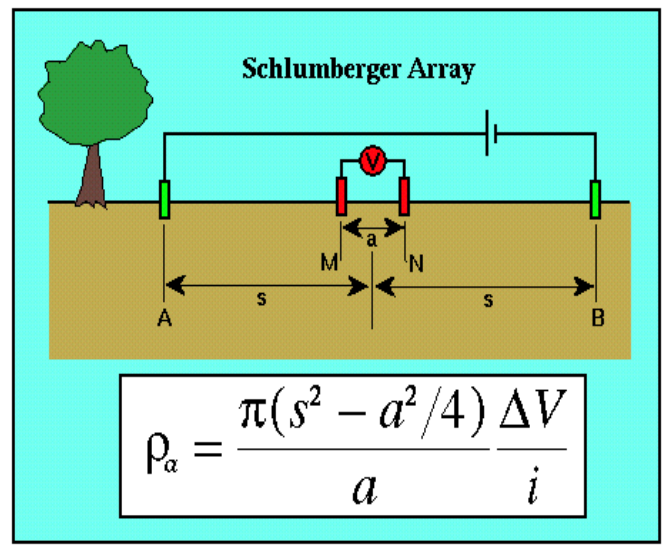

Figure 3a Schematic Diagram for Schlumberger array configuration

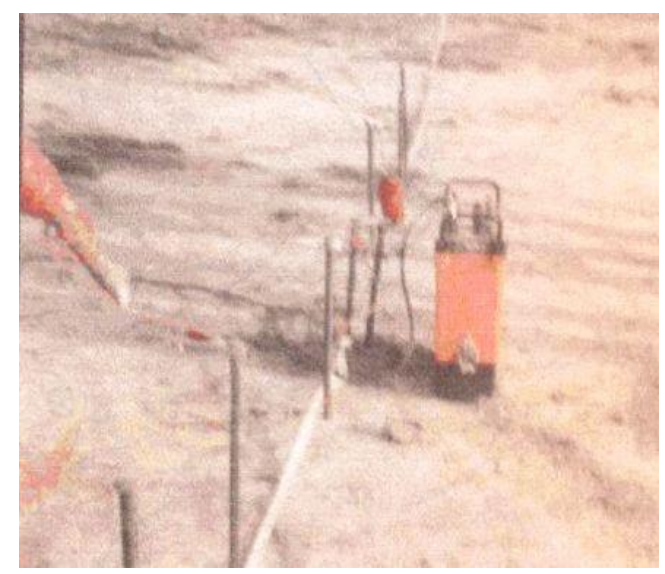

Figure 3b: A Typical Field Layout during Data Acquisition at the study area

Data collection, presentation and analysis

The values of $\Delta V / I$ obtained during the soundings were recorded against their respective electrode separation for both current and potential electrodes. The data were obtained in eight different stations within the study area, Schlumberger configuration were adopted throughout the survey as shown in Figure 3c.

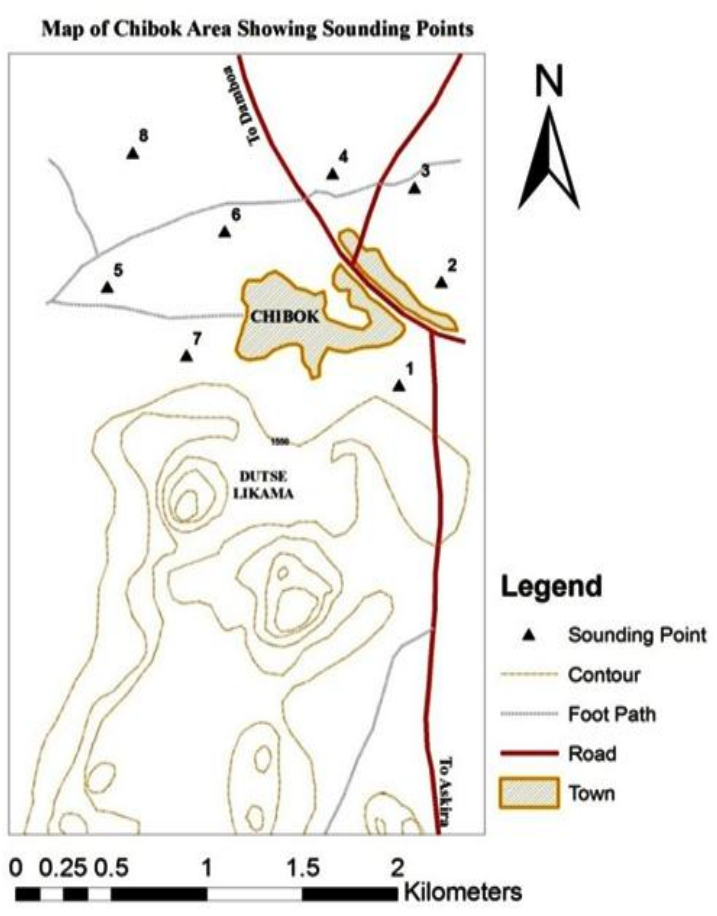

Figure 3c: Map of Chibok Area Showing Sounding Points

The terrameter readings are presented in $\Delta \mathrm{V} / \mathrm{I}$ (R) column, which will then be multiplied with a constant $\mathrm{K}$ to obtain the apparent resistivity values $(\rho \mathrm{a})$. All the apparent resistivity values are converted to ohm-meter. $A B / 2$, which is half the current electrode spacing, measured in meter and $M N / 2$, which is half the potential electrode separation can be tabulated in their various columns as seen in table 1 below.

Quantitative interpretation several methods are used in the quantitative interpretation of electrical sounding curves. These methods are classified as analytical (computer) and manual interpretation methods. The only sound basis for the quantitative interpretation of expanding electrode measurements is the use of appropriate theoretical curves. Sets of theoretical curves have been prepared for a number of cases involving 2, 3 and 4 layers of ranging resistivity's for both Werner and Schlumberger configurations ((Mooney and Wetzel, 1956; Mooney et al, 1966; Orellana and Mooney 1966; Van Nostrand and Cook, 1966)). For this study analytical method was employed 
using Geophysical application software for interpretation (WinResist).

\section{RESULTS AND DISCUSSION}

The field readings obtained is generally presented in Table 1. The results show variable layer resistivity of $(0.0 \Omega m-3.1 \Omega m)$ in the top soil (clayey or lateritic), $(3.1 \Omega \mathrm{m}-6.7 \Omega \mathrm{m})$ in the decomposed crystalline rock, $(6.7 \Omega \mathrm{m}-17.9$ $\Omega m)$ in the highly weathered crystalline rock, $(17.9 \Omega \mathrm{m}-38.4 \Omega \mathrm{m})$ in the weathered or fractured crystalline rock and (38.4 $\Omega \mathrm{m}$ infinity) in the weathered to fresh crystalline rock. Layer thickness vary from $1.8 \mathrm{~m}$ to $3.1 \mathrm{~m}$, $3.3 \mathrm{~m}$ to $6.7 \mathrm{~m}, 8.4 \mathrm{~m}$ to $17.9 \mathrm{~m}$, and $11.9 \mathrm{~m}$ to $38.4 \mathrm{~m}$ in the top soil clay layer highly weathered basement, and weathered basement, respectively.

From the interpretation of the results in the light of the foregoing discussion, VES 2, 3, 4, 6, 7, and 8 have meet requirement for groundwater accumulation. However, thicknesses of VES 1 and 5 may not favor accumulation of large quantity of groundwater

Table 1: Resistivity Survey Data Around Chibok, North-eastern Nigeria

\begin{tabular}{|c|c|c|c|c|c|c|c|c|c|c|c|c|c|c|c|}
\hline \multicolumn{2}{|c|}{ VES 1} & \multicolumn{2}{|c|}{ VES 2} & \multicolumn{2}{|c|}{ VES 3} & \multicolumn{2}{|c|}{ VES 4} & \multicolumn{2}{|c|}{ VES 5} & \multicolumn{2}{|c|}{ VES 6} & \multicolumn{2}{|c|}{ VES 7} & \multicolumn{2}{|c|}{ VES 8} \\
\hline$\overline{A B / 2(m)}$ & $\rho \mathrm{\rho}(\Omega \mathrm{m})$ & $\overline{A B / 2(m)}$ & $\rho \mathrm{pa}(\Omega \mathrm{m})$ & $\overline{A B / 2(m)}$ & $\rho \mathrm{pa}(\Omega \mathrm{m})$ & $\overline{A B / 2(m)}$ & $\rho \mathrm{pa}(\Omega \mathrm{m})$ & $\overline{A B / 2(m)}$ & $\rho a(\Omega m)$ & $\overline{A B / 2(m)}$ & $\rho \mathrm{a}(\Omega \mathrm{m})$ & $\overline{A B / 2(m)}$ & $\rho \mathrm{a}(\Omega \mathrm{m})$ & $\overline{A B / 2(m)}$ & $\rho a(\Omega m)$ \\
\hline 1.0 & 12.74 & 1.0 & 23.19 & 1.0 & 25.15 & 1.0 & 19.89 & 1.0 & 12.7 & 1.0 & 18.8 & 1.0 & 22.7 & 1.0 & 24.7 \\
\hline 1.5 & 12.44 & 1.5 & 20.23 & 1.5 & 18.94 & 1.5 & 18.20 & 1.5 & 11.5 & 1.5 & 16.0 & 1.5 & 20.5 & 1.5 & 21.3 \\
\hline 2.0 & 11.66 & 2.0 & 18.54 & 2.0 & 17.66 & 2.0 & 15.74 & 2.0 & 10.3 & 2.0 & 16.5 & 2.0 & 19.4 & 2.0 & 18.4 \\
\hline 2.5 & 11.44 & 2.5 & 18.07 & 2.5 & 18.16 & 2.5 & 14.71 & 2.5 & 11.0 & 2.5 & 13.8 & 2.5 & 18.8 & 2.5 & 17.3 \\
\hline 3.0 & 11.86 & 3.0 & 18.10 & 3.0 & 19.93 & 3.0 & 22.55 & 3.0 & 12.2 & 3.0 & 13.0 & 3.0 & 18.3 & 3.0 & 16.8 \\
\hline 4.0 & 13.13 & 4.0 & 20.74 & 4.0 & 24.13 & 4.0 & 15.86 & 4.0 & 13.1 & 4.0 & 14.3 & 4.0 & 20.3 & 4.0 & 16.9 \\
\hline 5.0 & 13.43 & 5.0 & 22.98 & 5.0 & 26.35 & 5.0 & 14.99 & 5.0 & 13.4 & 5.0 & 17.1 & 5.0 & 23.1 & 5.0 & 18.2 \\
\hline 6.5 & 12.88 & 6.5 & 25.55 & 6.5 & 31.46 & 6.5 & 18.65 & 6.5 & 12.9 & 6.5 & 25.5 & 6.5 & 24.3 & 6.5 & 20.2 \\
\hline 8.0 & 13.57 & 8.0 & 26.39 & 8.0 & 34.44 & 8.0 & 21.01 & 8.0 & 13.7 & 8.0 & 27.5 & 8.0 & 24.7 & 8.0 & 20.0 \\
\hline 10 & 13.82 & 10 & 25.84 & 10 & 35.43 & 10 & 20.58 & 10 & 13.0 & 10 & 31.6 & 10 & 23.6 & 10 & 20.5 \\
\hline 8.0 & 15.55 & 8.0 & 26.48 & 8.0 & 33.93 & 8.0 & 22.39 & 8.0 & 13.3 & 8.0 & 27.8 & 8.0 & 26.7 & 8.0 & 22.3 \\
\hline 10 & 15.42 & 10 & 25.55 & 10 & 34.96 & 10 & 22.83 & 10 & 14.5 & 10 & 29.9 & 10 & 25.6 & 10 & 22.8 \\
\hline 13 & 16.34 & 13 & 23.50 & 13 & 36.43 & 13 & 21.45 & 13 & 17.6 & 13 & 34.0 & 13 & 23.3 & 13 & 22.1 \\
\hline 16 & 18.23 & 16 & 22.20 & 16 & 34.51 & 16 & 20.51 & 16 & 19.9 & 16 & 32.0 & 16 & 20.6 & 16 & 21.1 \\
\hline 20 & 21.37 & 20 & 20.86 & 20 & 30.54 & 20 & 19.23 & 20 & 25.6 & 20 & 30.0 & 20 & 19.2 & 20 & 197 \\
\hline 25 & 29.46 & 25 & 19,83 & 25 & 25.86 & 25 & 18.66 & 25 & 31.5 & 25 & 26.9 & 25 & 17.7 & 25 & 18.8 \\
\hline 30 & 30.26 & 30 & 19.23 & 30 & 2234 & 30 & 18.47 & 30 & 36.3 & 30 & 25.3 & 30 & 179 & 30 & 199 \\
\hline 40 & 40.05 & 40 & 18.77 & 40 & 19.44 & 40 & 20.78 & 40 & 48.0 & 40 & 26.8 & 40 & 19.1 & 40 & 23.3 \\
\hline 50 & 48.96 & 50 & 20.16 & 50 & 19.99 & 50 & 23.83 & 50 & 58.8 & 50 & 31.5 & 50 & 22.3 & 50 & 26.4 \\
\hline 65 & 57.08 & 65 & 23.81 & 65 & 23.45 & 65 & 30.63 & 65 & 68.8 & 65 & 38.1 & 65 & 27.6 & 65 & 30.8 \\
\hline 80 & 65.02 & 80 & 29.49 & 80 & 27.48 & 80 & 34.86 & 80 & 78.0 & 80 & 52.3 & 80 & 34.6 & 80 & 38.4 \\
\hline 100 & 79.60 & 100 & 33.51 & 100 & 33.51 & 100 & 42.94 & 100 & 95.5 & 100 & 76.7 & 100 & 41.5 & 100 & 46.5 \\
\hline 80 & 63.78 & 80 & 29.66 & 80 & 27.27 & 80 & 32.68 & 80 & 11.7 & 80 & 45.6 & 80 & 57.3 & 80 & 35.9 \\
\hline 100 & 76.48 & 100 & 37.90 & 100 & 33.38 & 100 & 39.28 & 100 & 12.9 & 100 & 55.8 & 100 & 69.1 & 100 & 41.3 \\
\hline
\end{tabular}

\section{Geoelectric section}

The VES data interpretation delineates five major geologic units in the study area as shown in figure 4a. Geoelectric sections were taken along NE-SW direction with a view to correlating the geoelectric sequence across the study area. In the geoelectric section, depth of layer 1 ranges from $1.80 \mathrm{~m}$ to $3.10 \mathrm{~m}$. Depth of layer 2 ranges from $3.30 \mathrm{~m}$ to $6.70 \mathrm{~m}$, while depth of layer 3 ranges from $8.40 \mathrm{~m}$ to $17.90 \mathrm{~m}$, depths range from 11.90 to $38.40 \mathrm{~m}$ in layer 4 . The complete thickness of layer 5 was found only in VES where the layer has an end depth $58.5 \mathrm{~m}$ to infinity.

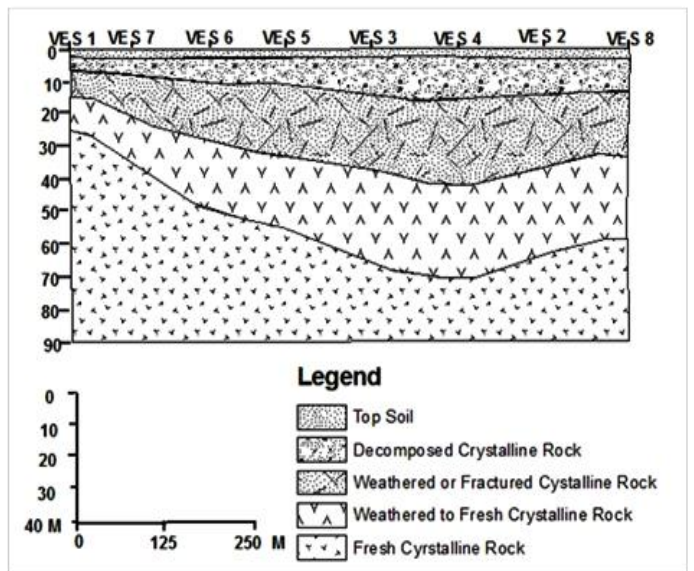

Figure 4a: Geoelectric Section of the study area 


\section{Isopach map of the overburden}

The established depths to the bedrock beneath all the VES stations occupied were plotted and contoured on an isopach map of the overburden. The overburden thickness in the study area varies from $15.30 \mathrm{~m}$ to $58.50 \mathrm{~m}$. Areas of thickness overburden are priority areas for groundwater exploration. The isopach map is shown in figure $4 \mathrm{~b}$ :

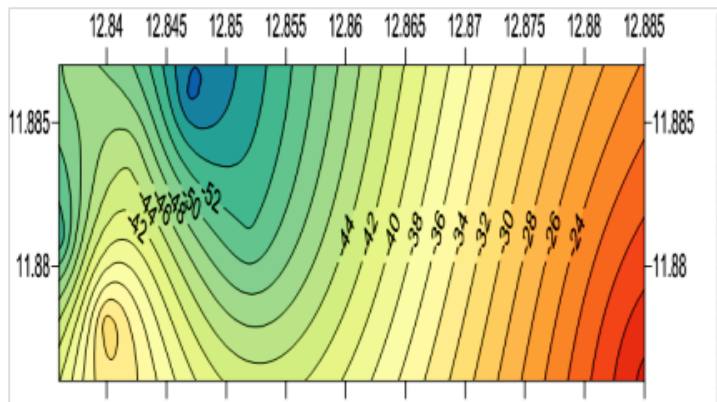

$\begin{array}{llllllllll}12.84 & 12.845 & 12.85 & 12.855 & 12.86 & 12865 & 1287 & 12.875 & 12.88 & 12.885\end{array}$

Figure 4b.Map of Overburden

\section{Basement relief maps}

This shows the subsurface topography of the bedrock across the study area. The hydrological significance of bedrock relief map has been recognized by Olorunfemi and Okhue (1992); Dan-Hassam and Olorunfemi (1999); Olorunfemi et al (1999); Bala and Ike (2001). Topographic depressions and ridges are identifiable in the bedrock relief map. Depressions are characterized by thickness overburden while ridges are noted for thin overburden covers Basement basement depressions constitute groundwater. Collecting troughs, especially from the bedrock crests (Figure 4c, Figure 4d \& Figure 4e).

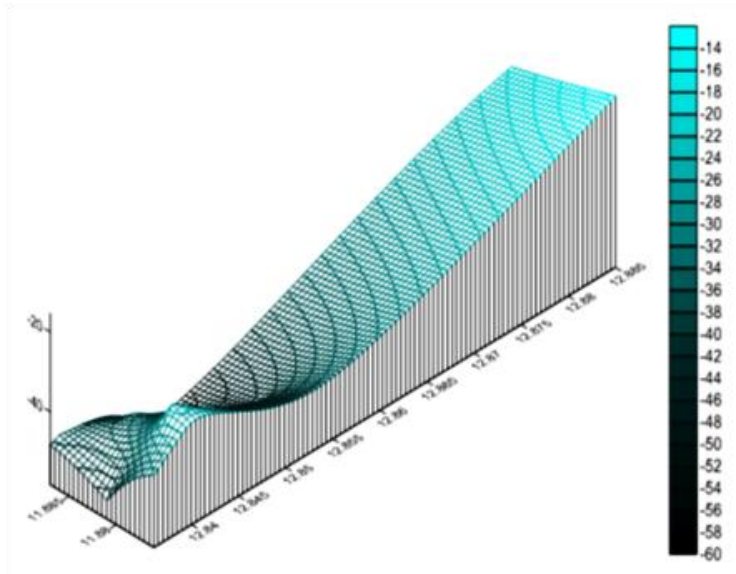

Figure 4c: 3D Relief Map of the Study Area

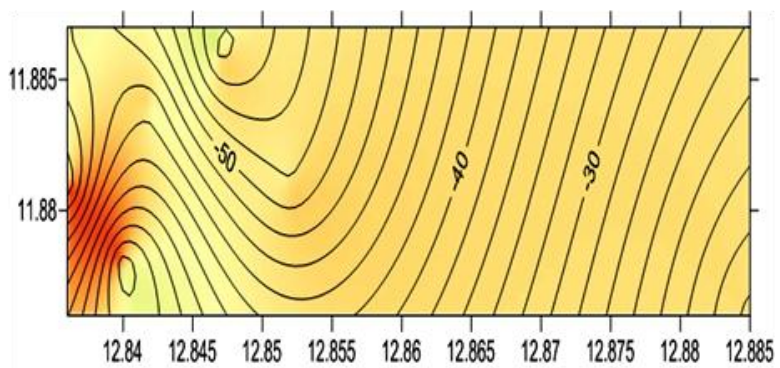

Figure 4d: Shaded Relief Map of the Study Area
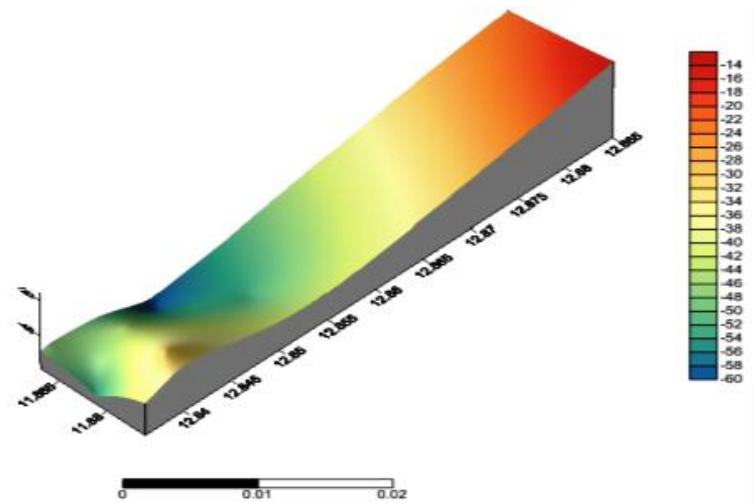

Fig. 4e: 3D Subsurface Map of the Study Area

\section{DISCUSSION}

The VES data acquired in the field were used in plotting the layer curve; analytical method approach was used in the interpretation of the curves which involved estimating number of layers, their approximate resistivities and thickness. However, the WinResist modelling programme did a more sophisticated interpretation where intermediate points are automatically calculated, and lateral errors computed for each measurement of the data set.

The thicknesses of overburden are used to evolve geoelectric section across the study area, isopach and the basement relief maps for thorough assessment of the groundwater potential of the study area. Below are the computer generated resistivity curves using WinResist software: 

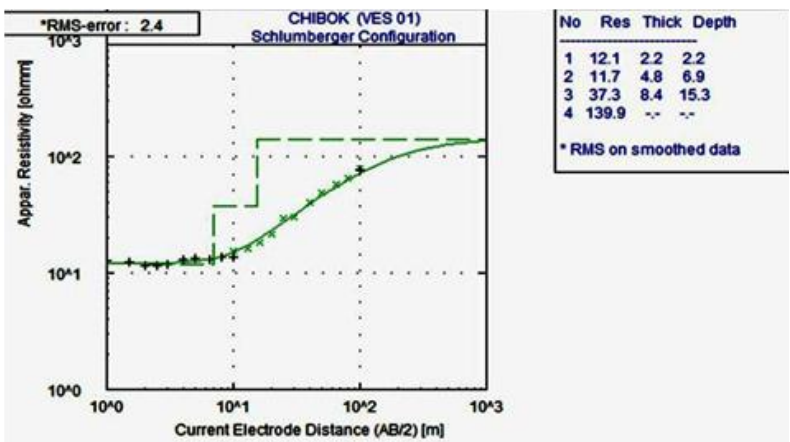

Figure 5(a): Resistivity Curve of VES 1
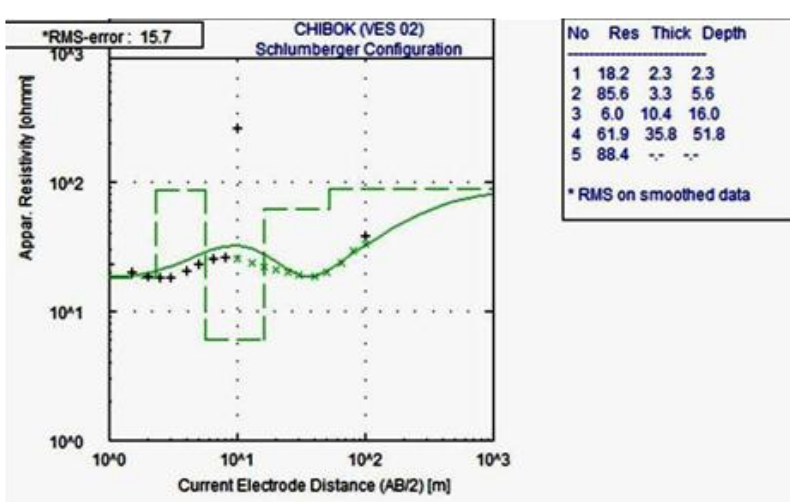

Figure 5(b): Resistivity Curve of VES 2
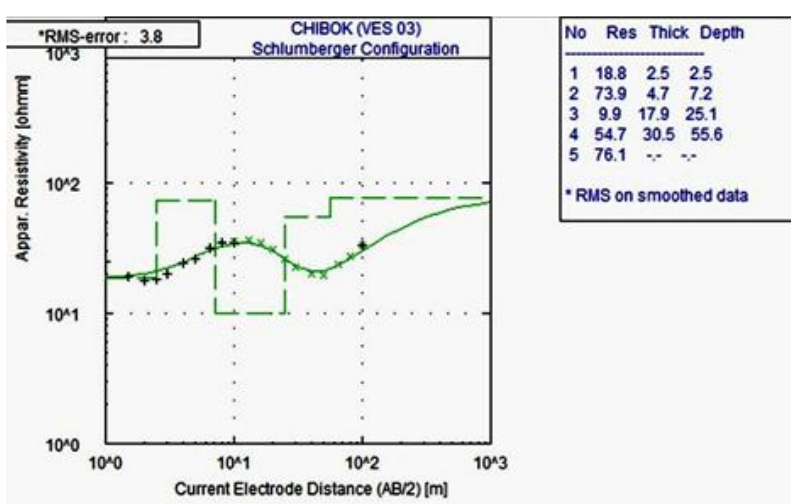

Figure 5(c): Resistivity Curve of VES 3
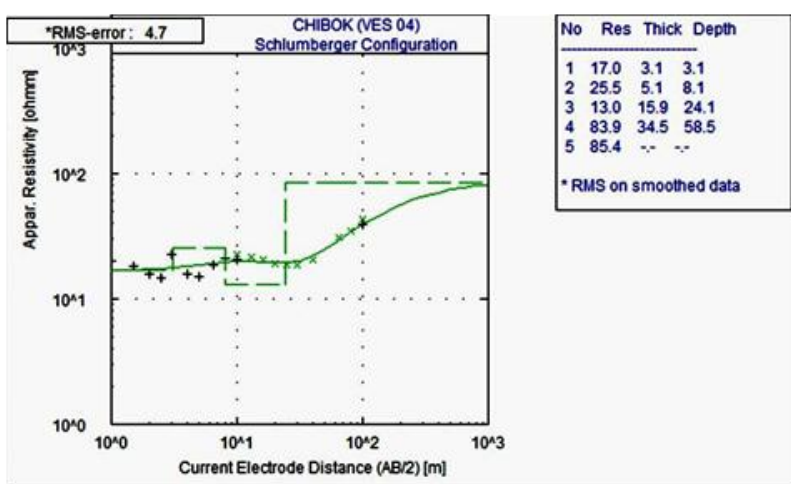

Figure 5(d): Resistivity Curve of VES 4
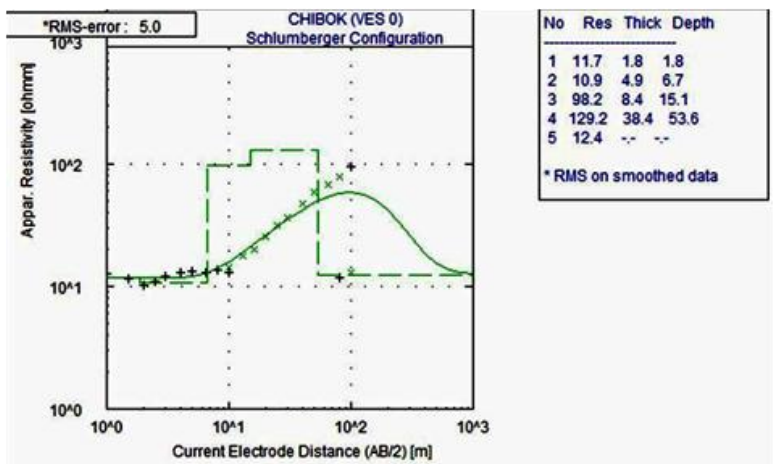

Figure 5(e): Resistivity Curve of VES 5
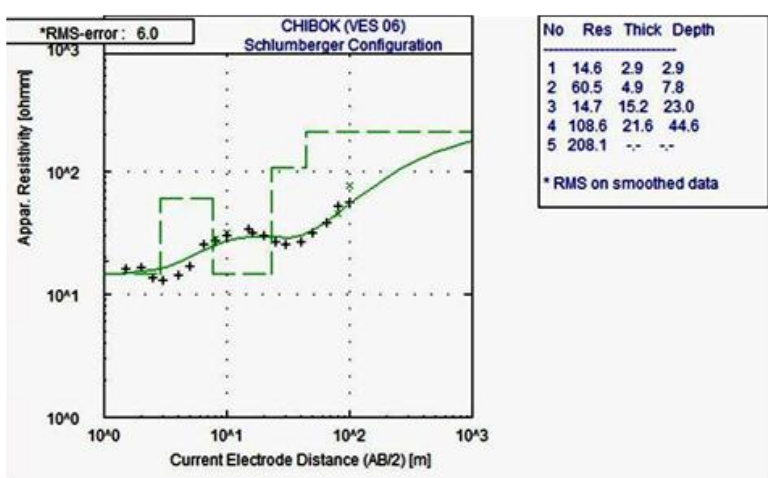

Figure 5 (f): Resistivity Curve of VES 6
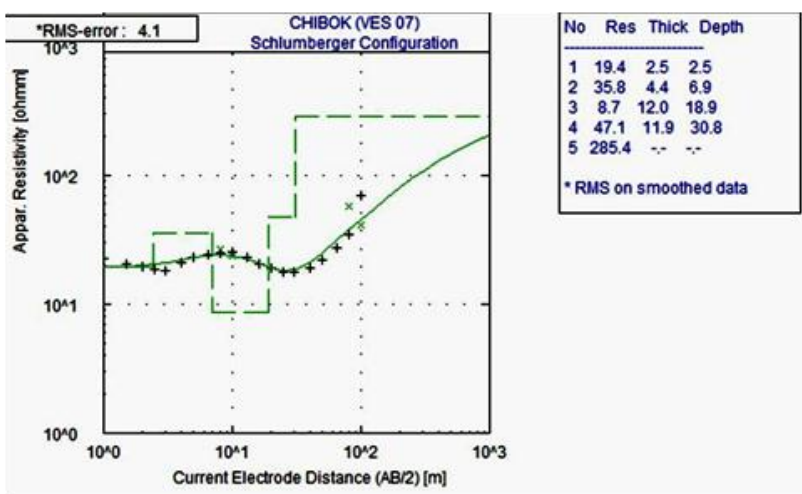

Figure 5(g): Resistivity Curve of VES 7

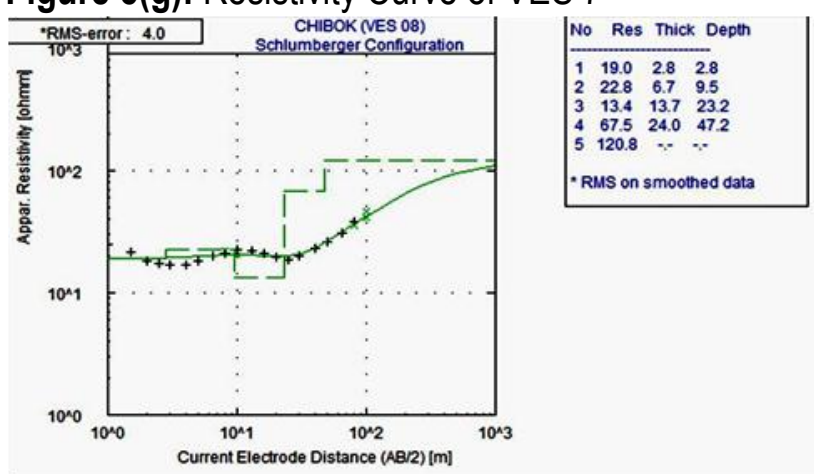

Figure 5(h): Resistivity Curve of VES 8

\section{CONCLUSION}

The study area has five geo-electric layers with the overburden thickness across the study area ranging from $11.7 \mathrm{~m}$ to $19.4 \mathrm{~m}$. Top soil forms 
the first layer at each VES point with resistivity values ranging from $0.0 \Omega \mathrm{m}$ to $3.1 \Omega \mathrm{m}$. The second layer is interpreted to compose of decomposed crystalline rock with resistivity values from $3.1 \Omega \mathrm{m}$ to $6.7 \Omega \mathrm{m}$. The third layer is a highly weathered crystalline rock due to low resistivity values of $6.7 \Omega \mathrm{m}$ to $17.9 \Omega \mathrm{m}$. The fourth layer is composed of weathered or fractured crystalline rock with resistivity values of $17.9 \Omega \mathrm{m}$ to $38.4 \Omega \mathrm{m}$, while weathered to fresh crystalline rock forms the fifth layer with resistivity values ranging from $38.4 \Omega \mathrm{m}$ to infinity.

Conclusively, the results suggests that VES 2, $3,4,6,7$, and 8 will be good for drilling because of their low resistivity values (possible saturation zones) with the aquifer thicknesses favouring accumulation of large quantities of groundwater; thus these curves conform more to the H-curve type which is typically found in a Basement terrain. VES 1 and 5 are more of an A-curve type having higher resistivity values with depth; as such these curves are not recommended for drilling.

In view of the persisting groundwater scarcity faced by Chibok community, the following recommendations may be considered:

1- More geophysical investigations of the area be carried out with emphasis on increasing the electrode separation and VES points to allow detail probing of the subsurface in order to produce high yielding boreholes.

2- A detailed 2D survey is also encouraged in order to reveal the true image of the sub-surface both radially and laterally, and also give an insight to the continuity of the various units.

\section{REFERENCES}

Arabi S. A., Dewu B. B. M., Muhammad A. M., Ibrahim M. B. and Abafoni J. D. (2010): Determination of weathered and fractured zones in part of the basement complex of North-Eastern Nigeria. Journal of Engineering and echnology Research Vol. 2(11), 213-218.
Bala, A.E. and Ike, E.G. (2001): The Aquifer of the crystalline basement rocks in Gusau area, Northwestern Nigeria. Journal of Mining and Geology, 37( 2):177-184.

Borno State Water Board (1989): Borehole Repots of Chibok Local Government area and its environs (Unpublished).

Chad Basin Development Authority (1987): Borehole Reports of Chibok Local Government Area and its environs (Unpublished).

Conred (Nig.) Limited (1978) A Report of Geophysical Investigation of Chibok Areas, Northeast (Unpublished)

Dan-Hassan, M.A., and Olorunfemi, M.O., (1999): Hdrogeophysical investigation of a basement a terrain in the north central part of Kaduna State, Nigeria. Journal of Mining and Geology, 35(2): 189-206.

Kogbe CA (1989). Geology of Nigeria. Second Edn., Abiprint and Pak limited, Ibadan, Nigeria.

Nur A.S and Kujir A.S (2006). Hydro geo-electrical study in the Northeastern part of Adamawa State, Nigeria. J. Environ. Hydrol., p. 14.

Mooney H. M., Orellana E., A. Pickett H. and Tornheim L. (1966): Resistivity Computation Method for Layered earth models. Geophysics, 31((1): 192-203.

Mooney H. M. and Wetzel W. W. (1956): Apparent resistivity curves for a two-three- and fourlayered earth. University of Minneasota, Minneapolis.

Mutah, A. (2002): Rural Water Supply in Chibok Local Government Area of Borno state. A final year project submitted to the Department of Geography, Unimaid (unpublished).

Olorunfemi, M.O. and Okhue, E.T. (1992): Hydrogeologic and Geologic significance of a geoelectric survey at lle-lfe, Nigeria-Journal of Mining and Geology, 28(2): 221-229.

Olorunfemi, M.O., Ojo, J.S. and Akintunde, O.M. (1999): Hydrogeophysical evaluation of the groundwater potential of Akure Metropolis, Southwestern Nigeria. Journal of Mining and Geology, 35(2): 207-228.

Orellana E. and Money H. M. (1966): Electrical sounding over layered structures. Interciencia, Madrid.

Van Nostrand G. and Cook, K. L. (1966): Interpretation of resistivity data U.S.G.S. Professional paper, 310p. 